Canadian University Music Review

Revue de musique des universités canadiennes

\title{
Kathryn Bailey, ed. Webern Studies. Cambridge: Cambridge University Press, 1996. xix, 375 pp. ISBN 0-521-47526-0
}

\section{Catherine Nolan}

Volume 20, numéro 2, 2000

URI : https://id.erudit.org/iderudit/1014469ar

DOI : https://doi.org/10.7202/1014469ar

Aller au sommaire du numéro

Éditeur(s)

Canadian University Music Society / Société de musique des universités

canadiennes

ISSN

0710-0353 (imprimé)

2291-2436 (numérique)

Découvrir la revue

Citer ce compte rendu

Nolan, C. (2000). Compte rendu de [Kathryn Bailey, ed. Webern Studies.

Cambridge: Cambridge University Press, 1996. xix, 375 pp. ISBN 0-521-47526-0].

Canadian University Music Review / Revue de musique des universités

canadiennes, 20(2), 132-141. https://doi.org/10.7202/1014469ar

All Rights Reserved (C Canadian University Music Society / Société de musique des universités canadiennes, 2000
Ce document est protégé par la loi sur le droit d'auteur. L'utilisation des services d'Érudit (y compris la reproduction) est assujettie à sa politique d'utilisation que vous pouvez consulter en ligne.

https://apropos.erudit.org/fr/usagers/politique-dutilisation/ 
texts (including their forms), and in his ability to enlist equally multifaceted musical resources to produce musical settings that profoundly and subtly enhance them without in any way distorting or obscuring. A distraction is her voice-leading sketches of portions of "Apparition" (examples 8.2, p. 186 and 8.5 ,p. 190), which are somewhat puzzling to decipher. In example 8.2 , for example, we are directed to note a "tenuous linear progression" (p. 185), which is generally understood to mean a stepwise diatonic motion in a single voice that connects two tones belonging to a single harmony (customarily notated as stemmed notes connected to a single beam), but such a structural interval (supported in the bass) is nowhere to be found; moreover, while the beginning of the figure shows $\mathrm{E}^{4}$ supporting G-sharp and $\mathrm{B}$ (-natural) above, it is beamed as an interval within a single harmony to B-flat ${ }^{3}$. This minor complaint aside (and these examples really are incidental to the discussion) this estimable article is a model for critical studies of text settings.

Richard Langham Smith's chapter (“'La jeunesse du Cid': A Mislaid Act in Rodrigue et Chimène") falls somewhere between "autograph studies" and "contextual issues," treating the subject of Debussy's early, unfinished opera, and in particular its outer form of three acts with four tableaux. Since Catulle Mendès's pronouncements to the Paris press declared there would be four acts with five tableaux, the question to be answered is whether there is a missing act to Debussy's extant holographs. Langham Smith reviews the Spanish and French literary sources that treat the Cid legend, alongside Mendès's comments, and concludes that there must have been another act, which has since been lost.

This uniformly strong collection of important essays by a group of well-known Debussy researchers is "must" reading for fin-de-siècle specialists, but it will also attract a much wider audience of scholars and music lovers. Its emphasis on "the music's context" cries out for a complementary collection of theoretical-analytical essays to treat "the music itself." Fortunately, such a volume is presently underway in the form of a Debussy Companion under the editorial direction of Simon Tresize (yet another Cambridge University Press project).

Richard S. Parks

Kathryn Bailey, ed. Webern Studies. Cambridge: Cambridge University Press, 1996. xix, 375 pp. ISBN 0-521-47526-0.

Webern Studies, edited by Kathryn Bailey, commemorates the fiftieth anniversary of Webern's death in 1945 with a collection of nine essays whose subject matter encompasses the composer's entire creative life and more. Six of the essays pursue analytical and critical studies of individual works or small groups of works: youthful vocal compositions predating his studies with Schoenberg (Rode-Breymann); early atonal works (Forte, Wason, Meyer and Shreffler); and mature works in the twelve-tone idiom (Wintle, Whittall). The three remaining essays contribute in rather different ways, both critical and practical, to Webern scholarship: one speculates with tongue in cheek on the fictive question of what might have transpired had Webern not relinquished the post-romantic idiom of 
his 1904 symphonic poem, Im Sommerwind (Puffett); one proffers the first comprehensive examination of the tables of row forms Webern constructed for each of his works from Op. 19 to Op. 31 (Bailey); the final contribution (Boynton) is a bibliography of scores or arrangements of Webern works, writings of Webern, and primary and secondary literature pertaining to Webern and his music published or made available after 1976.

That Webern Studies is eclectic in subject matter and scope is hardly a remarkable characteristic of a collection of essays by disparate authors. The eclecticism of the volume, however, only lightly veils a notable connecting thread between the essays, a multivalent revisionism intended to counterbalance the tenacious association of Webern's music with the positivistic ideology initiated by the young generation of post-war composers who discovered Webern's music for the first time in the early 1950 s. As Bailey remarks in the introduction to Webern Studies, a number of authors in recent years have responded to the compulsion to restore a sense of balance in Webern scholarship. Bailey attributes this response principally to new insights that have evolved through the accessibility of primary materials that became available to Webern scholars only in 1986, following the acquisition by the Paul Sacher Stiftung in Basel, Switzerland, of the collection of Webern materials previously in the possession of Hans Moldenhauer. It would be impossible to underestimate the scholarly and intellectual value of these primary materials, and indeed, as Bailey points out, most of the authors represented in Webern Studies enjoy familiarity with the materials, but important new perspectives and insights, including many in this book, derive from sources other than primary documents. Returning to the connecting thread of revisionism, however, it is important to note that the perspicacious ordering and subtle links between many of the essays make the whole more than the sum of its parts and augment the intrinsic value of the book. I will return to the book's revisionism in due course, following a survey of the nine essays in the order of their appearance. The order of the essays, with the exception of Boynton's bibliography at the conclusion of the book, reflects the chronological order of the central compositions discussed in each.

Susanne Rode-Breymann's essay, "“...Gathering the divine from the earthly...': Ferdinand Avenarius and His Significance for Anton Webern's Early Settings of Lyric Poetry" (translated by Mary Whittall), launches the collection with a historiographical consideration of cultural and artistic aspects of Webern's youthful settings between 1899 and 1904 for piano and voice of several contemporaneous poems by Ferdinand Avenarius. Rode-Breymann discusses the impact of the composer's close relationship with his older cousin, Ernst Diez, with whom the young Webern exchanged ideas on music and art throughout his formative years. In large part through the influence of Diez, Webern developed the interest in lyric poetry that endured throughout his life. The Avenarius settings were among Webern's earliest compositional efforts, but their significance is more than historical. They reveal his responsiveness to declamatory and rhetorical patterns of lyrical texts, especially in the absence of regular patterns of metre and rhyme. While Webern set texts from a diverse range of sources and poets over the course of his career, at critical stages in his creative evolution he 
identified preponderantly with specific poets: Richard Dehmel and then Stefan George in his early atonal works, Georg Trakl in his middle-period works, and Hildegard Jone in the mature twelve-tone works. Rode-Breymann's essay reveals Webern's affinity with the poetry of Avenarius in his earliest creative efforts, and sheds new light on the composer's precocious compositional concerns and practices before he came under the tutelage of Schoenberg.

The title of Derrick Puffett's essay, "Gone with the Summer Wind; or, What Webern Lost," alludes to another youthful work, the tone poem Im Sommerwind (1904) based upon a poem of Bruno Wille, which Webern completed shortly before his portentous first meeting with Schoenberg. Puffett's essay carries a further subtitle, "Nine Variations on a Ground," suggesting a creative (as opposed to documentary, historical, analytical, or critical) process involving successive rearticulations of a conception in new guises, analogous to the creative process of a composer. The essay's nine numbered sections constitute the "variations on a ground"; the ground or theme, seemingly, is "what Webern lost," or the conceit of a path not taken. Early in the essay, the trope of "what Webern lost" is framed rather prosaically:speculation on the type of music Webern might have written had he studied with Pfitzner (as he briefly considered) instead of Schoenberg, or if Schoenberg had continued to write music in the style of Verklärte Nacht, a work Webern had heard and deeply admired prior to his first meeting with Schoenberg. Later in the essay, the trope becomes more artfully framed: speculation about what Webern forfeited by rejecting the tonal language, by embracing atonality and later the twelve-tone method, and by accepting the artistic isolation to which his compositional choices led. Puffett provides a concise, but engaging analysis of Im Sommerwind whose fallout leads him to ruminations on post-romantic stylistic elements in the domains of harmony, phrase structure, orchestration, and large-scale form, and the vast range of influences upon Webern that these suggest; these elements constitute the essence of "what Webern lost" by virtue of the compositional constraints he imposed upon himself soon after the completion of Im Sommerwind.

In the last two sections of the essay, Puffett pursues his speculations into the realm of pure fantasy, culminating in an imaginative fabricated transcription of "the first page of a hitherto unknown tone poem from 1928, named Der schöne Spiegel" (p. 63). The year 1928 and the "beautiful mirror" in the fictitious title affiliate Puffett's imaginary tone poem with Webern's Symphony, op. 21, and indeed the "transcription" turns out to be an "enrichment" of the first ten bars of Webern's sparse, pointillistic symphonic score of 1928 with the addition of a gradually accumulated, sustained twelve-note chord in the muted (divisi) strings. The registral disposition of the pitches of the aggregate chord in the "transcription" corresponds to the mirroring of pitches in the Symphony around the A below middle $C$ that persists through the first section (bars 1-26), while the original string parts and a segment of the original harp part of the Symphony are assigned in the "transcription" to a colourful assortment of instruments not included in the original score (timpani, xylophone, celesta, guitar, and mandolin). The juxtaposition of this fanciful "transcription" with the opening bars of $I m$ Sommerwind lays bare Puffett's nostalgia. Statements such as "[i]t was only 
historical contingency, not the force of destiny, that prevented Webern turning out like Pfitzner or Franz Schmidt" (p. 65) or questions such as "At what point did purely musical ideals get sacrificed to intellectual ones?" (p. 69) tend to undermine the extent to which Webern shaped his own destiny and his deep intellectual and artistic commitment to the aesthetic and constructive ideals behind his music at every stage in his career, not to mention the obvious-that had Webern continued to write music in the idiom of Im Sommerwind, and not followed the path he embarked upon with Schoenberg, he surely would not have achieved the stature that he accrued posthumously, and there would be no Webern Studies in which to contemplate the trope of "what Webern lost" or, for that matter, what we have gained.

Allen Forte's essay, "The Golden Thread: Octatonic Music in Anton Webern's Early Songs, with Certain Historical Reflections," initiates a succession of three detailed studies of works from Webern's early atonal period. Forte analyses passages from the Dehmel Songs (1906-8), Four Stefan George Songs, Five Songs from 'Der siebente Ring' by Stefan George, op. 3, and Five Songs on Poems of Stefan George, op. 4, the latter three all dating from 1908-9, and explores various modes of octatonic expression in this early repertoire. Forte's investigation into the manifestation of octatonicism, a model of pitch organization familiar from analytic studies of the music of Stravinsky and Bartók, ${ }^{1}$ is highly original in the extensive analytical literature on Webern's music. ${ }^{2}$ Forte demonstrates early, intermittent octatonic apparitions in the Dehmel Songs, combining unordered subsets of two of the three unique forms of the octatonic in "Ideale Landschaft," the earliest of the Dehmel Songs. In the songs composed around 1908 and 1909, he reveals more complex interactions of two or even all three octatonic collections, usually emanating from a significant formation in the opening music in which the octatonic threads intersect and then separate. The most detailed analysis, that of "Kahl reckt der Baum," op. 3, no. 5, displays a complex intertwining of threads representing all three octatonic collections. Forte rec-. ognizes the analytical challenge posed by non-octatonic pitch formations; "we confront the unpleasant reality that not all of Webern's early songs fit the octatonic paradigm neatly-a considerable disappointment to the ever-hopeful analyst" (p. 77). He demonstrates consistent processes by which non-octatonic entities relate to an octatonic thread, such as prominent octatonic subsets, or the affiliation of symmetric components of a non-octatonic formation with two of the three octatonic collections. In the conclusion to his essay, Forte reflects on the origins of Webern's octatonicism and his (Webern's) attraction to the

\footnotetext{
${ }^{1}$ See Pieter van den Toorn, The Music of Igor Stravinsky (New Haven and London: Yale University Press, 1983), and Richard Cohn, "Bartók's Octatonic Strategies: A Motivic Approach," Journal of the American Musicological Society 44, no. 2 (1991): 262-300.

${ }^{2}$ See Forte's article "An Octatonic Essay by Webern: Opus 9/I of the Six Bagatelles for String Quartet," Music Theory Spectrum 16, no. 2 (1994):171-95. Forte's recent book The Atonal Music of Anton Webern (New Haven and London: Yale University Press, 1998) comprehensively explores Webern's entire corpus of atonal music from the early repertoire of Lieder for piano and voice surveyed in the Webern Studies essay, through to the Five Canons on Latin Texts, op. 16 (1923-24), Webern's last work before he adopted the twelve-tone method.
} 
octatonic model, proposing that Webern would not have surrendered to anarchy in making decisions about pitch organization upon abandoning the syntactical framework of tonality; he would have sought or created pitch formations that were related under some systematic set of guiding principles.

In "A Pitch-Class Motive in Webern's George Lieder, Op. 3," Robert Wason posits a particular pitch-class motive that carries a related contextual function in each of the five songs of Op. 3. A pitch-class motive denotes a set of privileged pitch classes whose compositional realizations will vary in terms of rhythmic, registral, dynamic, and timbral setting. In this way, a pitch-class motive contrasts sharply with the conventional understanding of motive, which is generally melodic or gestural and ordered, and in which rhythmic identity is often preserved, while contour may be retained or inverted under transposition or inversion. The pitch-class motive in Op. 3, which Wason refers to as "encircled $D$," consists of pitch class D and its surrounding pitch classes $C_{\sharp} \#$ and $E b$, and "recurs in a way that seems to give it special status, its contextual setting and larger meaning changing from one piece to the next" (p. 111). By the name Wason assigns to the motive, it is apparent that $\mathrm{D}$ acquires a higher degree of privilege than its neighbouring pitch classes in the motive. The manifestations of "encircled D" are wide-ranging: contiguous melodic segments in the first song; a network of $C_{\sharp}, D$, and $\mathrm{E}_{b}$ minor triads in the second song; a D pedal point governing the middle section of the third song, with $\mathrm{Eb}$ and $\mathrm{C} \#$ alternating in the "alto" register; two seemingly innocuous melodic occurrences in the fourth song that in fact articulate the formal division of the song; an implied and enhanced $\mathrm{D}$ minor harmonic context in the fifth song. The $\mathrm{D}$ minor context lends coherence to the "encircled D" motive throughout the songs of Op. 3, and supports existing studies contending that the tonal context of D minor held a special significance or meaning among the Second Viennese School composers. Wason argues, convincingly, that the prevalence of "encircled D" in the five songs of Op. 3, unique among Webern's fourteen George settings in 1908-9 (the Op. 3 songs, the Op. 4 songs, and the posthumously published Four Stefan George Songs), supports the textual unity of the songs, and provides substantial reason to conceive of them truly as a cycle.

The essay "Performance and Revision: The Early History of Webern's Four Pieces for Violin and Piano, Op. 7," by Felix Meyer and Anne Shreffler, recounts a fascinating history of performance and revision of a work which, contrary to most of Webern's music, was performed frequently during his lifetime. The first performance took place in 1911, the year following the completion of the violin and piano pieces, and the work was performed again in 1912; these performances featured the composer at the piano and two well-known violinists, Fritz Brunner and Arnold Rosé. The eight later performances discussed by Meyer and Shreffler, all taking place after the First World War, were organized under the auspices of the Verein für musikalische Privataufführungen, with Eduard Steuermann at the piano and, with the exception of the first post-war performance, the violinist Rudolph Kolisch. Between the pre-war and post-war performances, Paul Hindemith evidently expressed interest in performing the 
pieces, as did the American violinist Arthur Hartmann, known for his collaborations with Debussy and his interest in performing contemporary music. One of the most interesting features of the essay is a reproduction of a letter from Webern to Hartmann, poignantly dated 15 July 1914, just before the declaration of war in Austria, which responds to questions by Hartmann about how technically to achieve the composer's intended effect at certain places in the score. ${ }^{3}$

Although Webern revised several of his early compositions in the 1920s, none received the same amount of revision as the Op. 7 pieces, due most likely to the greater opportunities for performance they received. Meyer and Shreffler trace a complex history of "desk revisions," revisions to work out compositional problems, and "rehearsal revisions," revisions to work out performance problems, through the relatively numerous sources, mostly autograph scores. The earliest revisions, those made prior to the first performance, were principally revisions of pitch content, and the authors consider the analytical implications of such changes. ${ }^{4} \mathrm{~A}$ second stage of revisions, those made in preparation for the earliest performances and for anticipated publication, mainly involved fine-tuning of timbre and articulation in the violin part (e.g., revisions in the use of the mute or the indication Am Steg, refining the indication col legno with additional modifiers such as weich gezogen, gerissen, or heftig), as well as revisions in pitch material and texture. A final stage of revisions, in keeping with the ideals of the Verein für musikalische Privataufführungen, was directed towards achieving greater lucidity of texture and phrase structure, and greater clarity of pitch structures, involving mostly small but significant adjustments to rhythmic durations, articulations, and dynamic levels, and some revision to pitch content. Perhaps the most profound revision, and one of the last before the publication of Op. 7, was the revision of the ending to the fourth and final piece. The original ending consisted of two inchoate, unpitched slides (glissandi) on the G string, which Webern notated in the definitive version as a seven-note, rhythmically articulated figure in sixteenth notes, whose pitch-class content correlates neatly with other set classes in the piece. This revision drastically alters the original ending, which averts a sense of closure and is not fully controlled (by the composer), to one of integration and closure not only of the piece, but of the entire opus. ${ }^{5}$ The authors' painstaking study of Webern's extensive revisions to Op. 7

${ }^{3}$ The letter is housed in the Special Collections at the Sibley Music Library, Eastman School of Music, University of Rochester.

${ }^{4}$ Meyer and Shreffler have written in more detail about the issue of analytical implications of Webern's sketches elsewhere. See Felix Meyer and Anne C. Shreffler, "Webern's Revisions: Some Analytical Implications," Music Analysis 12 (1993): 355-80. See also Allen Forte, “A Major Webern Revision and Its Implications for Analysis," Perspectives of New Music 28, no. 1 (1990): 224-55, which examines in detail Webern's revisions to the second of the Op. 7 pieces.

${ }^{5}$ This is not to undermine Webern's intentions when he wrote the work. Webern's conviction about the original ending in 1914 is clear from his letter to Hartmann, in which he writes, regarding the ending of the fourth piece: "I don't want the harmonics that result from lightly touching the string to be too clearly audible.... A sound more like noise." [Ich möchte nicht, daß die beim leichten Berühren der Saite entstehenden Flageoletts allzudeutlich hörbar werden. ... Mehr ein Geräusch ähnlicher Klang.] Quoted and translated in Meyer and Shreffler (p. 167). The reproduction of the complete letter appears on pp. 140-41. 
from its initial completion in 1910 up to its publication by Universal Edition in 1922 is highly revealing of Webern's changing aesthetics and compositional values over a period of more than a decade. It also reveals Webern's sensitivity to the material sound of his music and the role of performers, a sensitivity that has been largely misunderstood or ignored.

With Kathryn Bailey's important contribution to the volume, "Webern's Row Tables," the focus shifts to the composer's twelve-tone works. Bailey's article provides the first comprehensive study of Webern's row tables, the existence of which was known for decades, but their location was not generally known until their recovery by Regina Busch, announced in $1988 .{ }^{6}$ Now in the possession of the Paul Sacher Stiftung in Basel, Switzerland, the row tables are accessible for scholarly study, for which Bailey's study will serve as an indispensable guide. Webern constructed tables of row forms for all his works composed with the twelve-tone method, beginning with the Two Songs on Texts by Goethe, op. 19, his first completed twelve-tone composition to use a single row for all movements of the work. ${ }^{7}$

Bailey examines the tables in meticulous detail, describing such features as Webern's use of Roman and Arabic numerals in numbering the row forms from 1 to 48 , his use of colour schemes to correlate row forms in the tables with the compositional sketches, his use of enharmonic respellings, and even his use of thumbtacks to secure the tables (which required two or three sheets of manuscript paper to show all 48 row forms) on a board mounted on the composer's piano. The tables for rows that embed retrograde or retrograde-inversional symmetries are particularly interesting, as they reveal Webern's awareness of redundant row forms. In the tables for the Symphony, op. 21, the String Quartet, op. 28, the Cantata no. 1, op. 29, and the Variations for Orchestra, op. 30, he identifies duplicate row forms, but not in exactly the same way. His methods for indicating the redundant row forms became more refined as he gained experience and developed more efficient shorthand methods of keeping track of such relationships, although his adherence to the systematic transpositions of the basic complex of four row forms precluded the clearest revelation of the symmetries among the totality of row forms in these works. Bailey expresses her disquiet at Webern's inconsistencies and untidiness in the tables with respect to such matters as the use of accidentals, ordering of transpositions, and his practice of writing out retrograde forms in full, when Schoenberg and Berg did not find this necessary; she finds that these inconstancies call into question Webern's full understanding of the symmetric and other properties of the system. One must proceed cautiously, of course, in drawing conclusions from what are ultimately private working materials and cannot be regarded as a complete record of the composer's understanding of a complex system. But indeed, it is

\footnotetext{
${ }^{6}$ See Regina Busch, “A Recent Webern Discovery,” Tempo, no. 165 (1988): 58.

${ }^{7}$ As Bailey points out (pp. 222-23), the row tables recovered by Busch (which had been in the possession of Friedrich Wildgans) do not include some earlier tables housed at the Pierpont Morgan Library in New York. These include tables for an unfinished piano piece and for songs 2 and 3 of Three Songs, op. 18. (Each song of Op. 18 uses a separate row, and so requires a separate table.) These early row tables consist only of the small number of row forms used in the piece.
} 
interesting to contemplate Webern's adherence for twenty years to essentially the same format he adopted in the mid-1920s for writing out row forms and encapsulating the range of transformational possibilities, and to wonder, considering his consciousness of multi-dimensional space, why he did not (apparently) consider displaying row transformations in the form of a matrix, as Bailey muses (p. 225). Whatever conclusions one is tempted to draw from the row tables, they offer a compelling vantage point from which to (re)consider Webern's twelve-tone works and a profoundly human portrait of the composer.

Christopher Wintle, in "Webern's Lyric Character," considers Webern's lyricism, a quality of his music previously acknowledged but infrequently examined in a serious manner by Webern critics and scholars. In defining the expression lyric character, Wintle borrows from Hegel's opposition of the lyric and the dramatic, and Dahlhaus's description of the innate contrasts between the individual expression of a "lyric ego" in the Lied and the more public narration of a sequence of events in the ballad, before quoting a number of statements by Schoenberg and others extolling a developmental type of lyricism (pp.231-35). Through a focused study of the third song from Op. 25, on a text by Hildegard Jone, "Sterne, ihr silbernen Bienen der Nacht" ("Stars, you silver bees of the night"), Wintle purports to offer a model for further study of the lyric character of Webern's twelve-tone music. He considers particular qualities of the metaphorical domain of Jone's poetic text in response to Webern's personal affinities (e.g., unthreatening natural objects or beings, and transient moments of ecstasy) in the preliminary discussion of lyric character. He later considers syntactic and semantic relations within the vocal line, following a brief excursion to a discussion of a Schubert song, which Wintle exploits in order to polarize the extremes of expression and declamation. He examines details of row usage and invariance in the voice and piano parts separately before a undertaking a holistic analysis of the voice and piano parts in relation to each other, in which local events are related to large-scale or global ones. Lyric character seems to emerge from the association of large-scale events (in Wintle's analysis, all in the vocal line), into a große Linie.

In "Music - Discourse - Dialogue: Webern's Variations, Op. 30," Arnold Whittall too turns to the relation of music and language, but in a limited sense specifically reserved for the practice of analysis. His concern lies not with critical questions of artistic situation, context, signification, and communication, but with "the interpretations of possible parallels between verbal texts ... and a musical work" (p. 268). Quoting Robert Hatten, he defines musical discourse as "the strategic or thematic/topical flow of ideas in a musical work" (p. 268). ${ }^{8}$ Inspired by Bakhtin's concept of dialogism, Whittall invokes the dialogistic metaphor to model not the relationships between instrumental voices or row strands, but the interaction of the expressive and the formal. ${ }^{9}$ A musical discourse, then, is contingent on oppositions or dialogues at various levels. In his analysis of the Variations for Orchestra, Whittall describes the theme (bars 1-

\footnotetext{
${ }^{8}$ Robert S. Hatten, Musical Meaning in Beethoven: Markedness, Correlation, and Interpretation (Bloomington and Indianapolis: Indiana University Press, 1994), 289,

${ }^{9}$ Michael Holquist, Dialogism: Bakhtin and His World (London and New York: Routledge, 1990).
} 
20) as representing an expressive dialogue between the lyric and the dramatic, or the vulnerable and the assertive, articulated by the formal dialogue between and within the component parts of the period (bars 0-9 and 10-20).

Parallel to the model of music as discourse, Whittall poses the paradigm of Goethean metamorphosis to model the structural principle of organic growth. Webern's abiding interest in Goethe's philosophy and theories of nature is well documented, and indeed he wrote about the composition of Op. 30 to Hildegard Jone (the author of the poetic texts he set exclusively after 1933 and a kindred spirit), explicitly describing the process of variation as metamorphosis. ${ }^{10}$ The analogy of variation and metamorphosis is projected in both formal and transformational terms in Op. 30, and still admits the oppositions of expressive topics such as the lyric and dramatic. The result is an enrichment of the analytical arena in the search for elusive musical meaning in an instrumental work.

Of the final contribution to the volume, Neil Boynton's "A Webern Bibliography," there is little one can say except to express a profound debt of gratitude. Boynton's compilation supplements the earlier efforts of Zoltan Roman, who compiled and edited the bibliographies for Moldenhauer and Moldenhauer's Anton Webern: A Chronicle of His Life and Work and his own Anton von Webern: An Annotated Bibliography. ${ }^{11}$ The literature on Webern's music and life, which was voluminous at the time of Roman's bibliographies, has burgeoned since then, and an updated Webern bibliography was long overdue.

The essays in Webern Studies collectively examine works from early and late in the composer's career, leaving virtually untouched the entire middle-period works, generally understood to include the repertoire consisting exclusively of vocal works, from Op. 12 to Op. 19, and overlapping the shift in pitch organization from "free" atonality to the twelve-tone system. One of the authors represented in Webern Studies, however, Anne Shreffler, has contributed the most important single study of the middle-period repertoire with her exhaustive study of Webern's settings of texts by Georg Trakl. ${ }^{12}$ Naturally, a single collection of essays could not aim for complete coverage of all works or genres of a single composer, even one like Webern, who wrote comparatively few and short works.

Although the editor claims that Webern's lyricism supplies a thread that runs through the book, I would suggest that the running thread, so to speak, is not lyricism, but the book's revisionist stance. Each of the essays presents a revisionist point of view from one or more perspectives: revisionism in the form of new knowledge deriving from primary sources (Rode-Breymann, Meyer and Shreffler, Bailey); historical revisionism (Rode-Breymann, Puffett, Bailey, Wintle); revisionism in analytical or critical methodology (Forte, Wason, Wintle, Whittall). The gap in terms of repertoire is closed by the revisionist thread that unifies the collection in a manner that transcends its contents.

\footnotetext{
${ }^{10}$ Anton Webern, Letters to Hildegard Jone and Josef Humplik, ed. Josef Polnauer, trans. Cornelius Cardew (Bryn Mawr: Presser, 1967), 42. Quoted in Whittall (p. 264).

${ }^{11}$ Hans Moldenhauer and Rosaleen Moldenhauer, Anton Webern: A Chronicle of His Life and Work (London: Gollancz, 1978; New York: Alfred A. Knopf, 1979), 757-73; Zoltan Roman, ed., Anton von Webern: An Annotated Bibliography (Detroit: Information Coordinators, 1983).

12 Anne C. Shreffler, Webern and the Lyric Impulse: Songs and Fragments on Poems of Georg Trakl (Oxford: Clarendon Press, 1994).
} 
Webern Studies makes an important contribution. It offers a representative sample of recent Webern scholarship, confirms that Webern scholarship is alive and thriving, and holds out the promise that the "breath of life" (p.xvi) achieved in this volume will find continued expression in future Webern scholarship.

Catherine Nolan

Judith Tick. Ruth Crawford Seeger: A Composer's Search for American Music. New York and Oxford: Oxford University Press, 1997. xiv, 457 pp. ISBN 0-19506509-3 (hardcover).

Joseph N. Straus. The Music of Ruth Crawford Seeger. Cambridge: Cambridge University Press, 1995. xii, 260 pp. ISBN 0-521-41646-9 (hardcover).

Although Ruth Crawford Seeger (1901-53) wrote the majority of her original compositions during the 1920 s and early 1930 s - after this period, she wrote an orchestral fantasy in 1939 and her Suite for Wind Quintet in 1952-most of her work first appeared in print beginning in the 1970s. Only her Three Songs to Poems by Carl Sandburg (1930-32) and her String Quartet 1931 were published during her lifetime (1933 and 1941, respectively). This publication record speaks to the renaissance of her work in the last two decades, a period characterised by increasing attention to the musical contributions and lives of women composers. With Judith Tick's biography we can explore and appreciate Crawford's musical development and career in the context of her life story, and with Joseph Straus's analytical study of her music, we can understand from a theoretical perspective the musical structure and style of her modernist compositions.

Judith Tick's biography traces significant events that shaped Crawford's personal and professional lives. The commentary is based on diary entries, letters, poems, critical reviews, and Ruth Crawford's own autobiographical sketch (ca. 1947). Tick illuminates the literary value of Crawford's writings, and indeed admits her own fascination for how Crawford "construct[s] her life as literature" (p. 297). In addition, Tick provides a broader social context by exploring Crawford's mature life; political history also comes into play, especially through husband Charles Seeger's interest in politics and proletarian music. What Tick accomplishes here is quite staggering-she explores Crawford's personal and professional life through the lens of American social, historical, political, and musical history. She does all of this with a feminist sensibility, thereby making a major contribution to the field of women's studies, providing a model of how to write a female composer's life.

Tick's feminist contribution exists not only in the fact that she is offering a careful study of a woman's life and professional contributions. It is partly that, of course, but the feminist content exists more in the emphasis on gender and its role in the life and work of this individual. Tick is not only interested in the life events as absolute facts, but also in how various social factors effected and affected those events. One very strong message that emerges from Tick's narrative is that the personal and the professional sides of Crawford's life created two equally powerful forces on the composer, who constantly strove to achieve 